\title{
Potential of sinking zooplankton carcasses for organic matter export to fuel deep-sea life
}

\author{
BELEN FRANCO-CISTERNA ${ }^{1}$, PETER STIEF $^{2}$, ANNI \\ GLUD $^{2}$, ARKA RUDRA ${ }^{3}$, HAMED SANEI $^{3}$, MIE S \\ WINDING $^{4}$, TORKEL G NIELSEN ${ }^{5}$ AND RONNIE N GLUD $^{2}$ \\ ${ }^{1}$ University of Southern Denamrk \\ ${ }^{2}$ University of Southern Denmark \\ ${ }^{3}$ Aarhus University \\ ${ }^{4}$ Greenland Institute of Natural Resources \\ ${ }^{5}$ Technical University of Denmark \\ Presenting Author: belen@biology.sdu.dk
}

Organic matter produced in surface waters is the primary food supply to deep-sea ecosystems. In contrast to phytoplankton aggregates and zooplankton fecal pellets, sinking zooplankton carcasses have rarely been considered as important agents of organic matter export, despite their prevalence in the water column. The efficiency of organic matter export to the deep sea depends on how fast zooplankton carcasses sink in relation to how fast they are degraded by microbial activities. Here, we studied the degradation kinetics of sinking carcasses of the small, cosmopolitan copepod Acartia tonsa and the two large krill species Thysanoessa raschii and Meganyctiphanes norvegica from the Arctic.

Zooplankton carcasses are exposed to regionally varying surface temperatures and sink through a vertical gradient of temperature in the water column. Quantification of aerobic microbial respiration, as a proxy of carbon mineralization, indicated that copepod carcasses are degraded in time scales of days to weeks at high temperatures $\left(16-20^{\circ} \mathrm{C}\right)$ and weeks to months at low temperatures $\left(4-8^{\circ} \mathrm{C}\right)$. Taking the relatively slow sinking rates of copepod carcasses into account, their microbial degradation is likely constrained to the surface ocean in warmer regions. In contrast, copepod carcasses can reach the deep ocean in colder regions and thereby contribute to organic matter export.

The rapidly sinking krill carcasses can reach the deep sea and even the hadal realm within 2-4 days. Pyrolytic analysis of krill carcasses incubated for 7 days at in situ temperature revealed that only the labile carbon fraction is degraded during this short period. Thus, the large krill carcasses have a considerable potential to fuel deep-sea and hadal ecosystems with large amounts of semi-labile and semi-refractory organic carbon. 